Reprod. Nutr. Dévelop., 1988, 28 (5), 1225-1235

\title{
Quantitative ultrastructural analysis of the principal cells in the human epididymis
}

\author{
E. VENDRELY, J. P. DADOUNE
}

Groupe d'Etude de la Formation et de la Maturation du Gamète mâle, Laboratoire d'Histologie, Embryologie et Cytogénétique,

Faculté de Médecine Broussais-Hôtel Dieu et UER Biomédicale. 45, rue des Saints-Pères, F 75270 Paris Cedex 06.

Summary. A morphometric study of the principal epithelial cells of the epididymis has been carried out in six young adult men. Samples were taken in the head, body and tail of the epididymis and processed for ultrastructural study. The cytoplasm was subdivided into four zones. Their section areas were measured by planimetry and the volume density of cytoplasmic organelles assessed using the point-counting method. The general organization of the principal cells of the epididymis was identical along the duct. Quantitative analysis revealed that cells of the head contained significantly larger amounts of coated-vesicles and of Golgi saccules than the body and the tail. The functional implications of these results is important for the understanding of receptor-mediated endocytosis and protein synthesis in the different parts of the human epididymal duct.

\section{Introduction.}

The human epididymis is anatomically subdivided into three parts. The head, conical in shape, is joined to the ductuli efferentes by T-shaped end-to-side connections (Jonte and Holstein, 1987). The body is slender. The tail progressively enlarges and forms an acute $\mathrm{V}$-shaped angle which is prolonged by the deferent duct.

Cytological studies have shown that the head is composed of two segments, whereas the body and the tail are respectively made up of three segments (Holstein, 1969).

In rodents the three anatomical zones play different roles with respect to maturation of spermatozoa during their transport along the epididymal duct (Moore and Bedford, 1979). The epididymis is the site of simultaneous absorption and secretion (review in Cooper, 1986 ; Djakiew et al., 1986 ; Hinton and Hernandez, 1987). Descriptive cytology suggests that man does not differ essentially from other mammals in this regard (Holstein, 1969 ; Vendrely, 1981). 
As direct experiments in man are impossible for obvious technical and ethical reasons, the quantitative analysis of cytoplasmic organelles in electron microscope micrographs provides an indirect but accurate means of evaluating the localization and amount of cell activity (Weibel, 1969). Quantitative ultrastructural data have been provided in some rodents (Greenberg and Forssmann, 1983 ; Paulson, Byers and Dym, 1985), but not in man up to now.

In the present study ultrastructural morphometry was used to examine whether significant differences in the amount of some cytoplasmic organelles could be found in the principal cells of the human epididymal epithelium, suggesting a regional specialization.

\section{Material and methods.}

Epididymides, obtained from six young adult men with proven brain death, were carefully dissected. Samples of three zones were taken: initial part of the head (segment $2 \mathrm{a}$ of Holstein), middle part of the body (segment $3 \mathrm{~b}$ ) and distal part of the tail (segment $4 b$ ).

Tissues were fixed in $3 \%$ glutaraldehyde in S-collidine buffer and post-fixed in $2 \%$ aqueous osmium tetroxyde. Small blocks of tissue were embedded in Epon and ultrathin sections were stained with uranyle acetate and lead citrate, then examined with a JEOL 120 EM electron microscope. Photographs were taken at a magnification of $6000 \times$. Positive prints (final magnification $18000 \times$ ) were mounted to obtain a full picture of the supranuclear and basal parts of the cells. Fifty-four cells were examined, fifteen for the head and the tail, and twenty-four for the body of epididymis.

Counts were made on sections parallel to the long axis of the cells, passing through the nucleus. Cytoplasmic zones were defined by drawing transversal lines bounding the upper and lower limits of a region rich in dense body clusters situated in the middle of the supranuclear part of the cell. Cytoplasmic areas were measured by planimetry using a digitalizing table HI-PAD (Houston Instruments) connected to an APPLE II microcomputer (software modified from Houston Instruments Users Group).

Morphometry was performed using the modified point-counting method (Chalkley, 1943 ; Weibel, 1979). A square grid printed on a transparent sheet-film was placed over micrographs. The space between the lines of the lattice was $1 \mathrm{~cm}$. The intersections were used as test-points and their number overlying selected organelles was counted. The volume density was expressed in percentages as the fraction of the total number of points enclosed in the area. Relating the data to the area of the cytoplasm, by zone or in the whole cell, the true section area of each set of organelles could be obtained. Using the final magnification coefficient, the values were expressed in square micrometers. Data were subjected to an analysis of variance; the standard error was corrected for the number of counted points per each type of organelle (Weibel, 1979). Significant differences were defined at a probability level of 0.05 . 


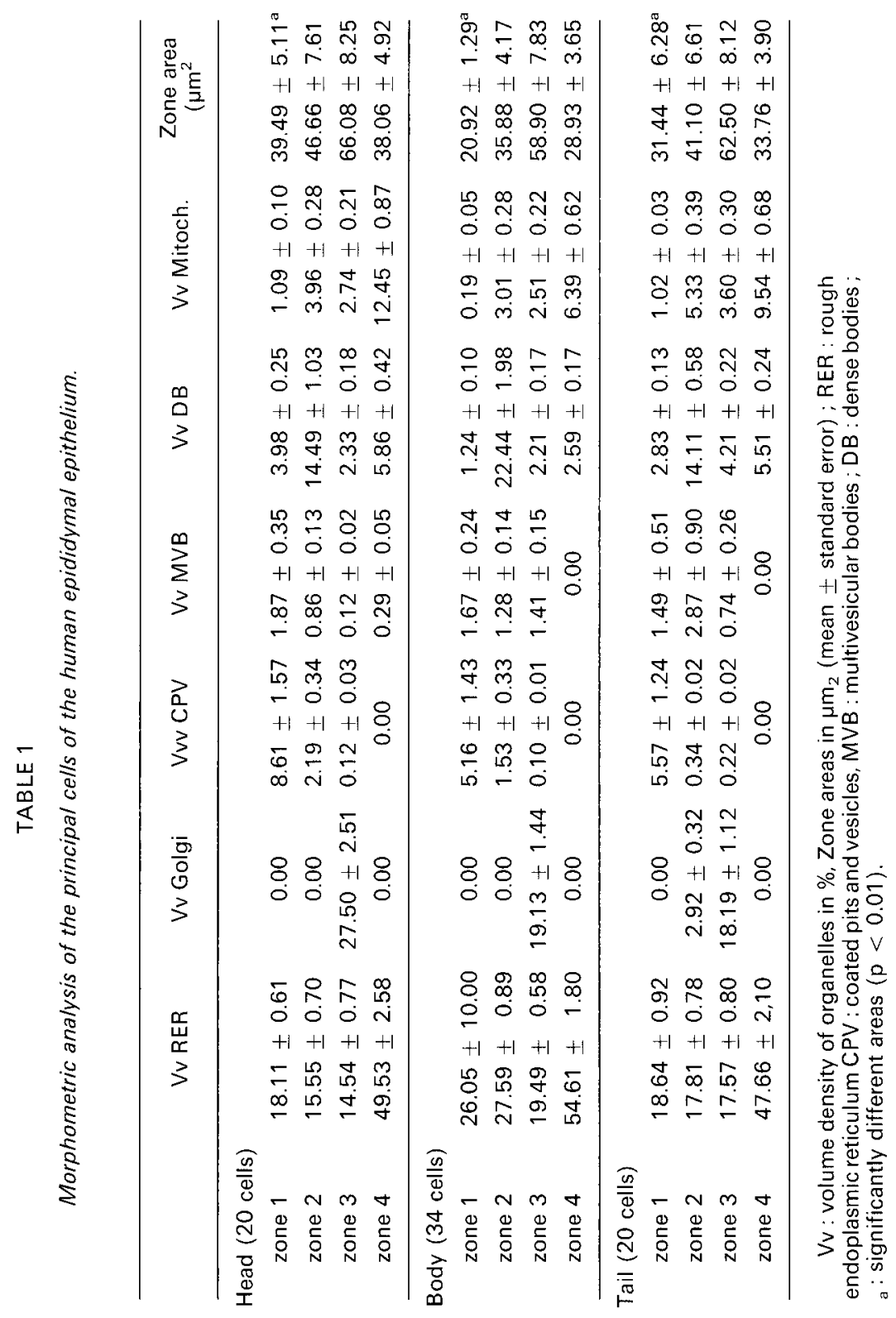




\section{Results.}

The principal cells of the human epididymis epithelium appeared as highly polarized cells displaying the same general organization from head to tail of the organ. Above the elongated nucleus, the upper half of the cell was clearly subdivided into three levels, the intermediate level containing an accumulation of dense bodies. Table 1 shows the volume density of some cytoplasmic organelles in the three supranuclear zones (respectively 1,2 and 3 from the apex to the nucleus) and in the infranuclear zone. The thin rim of cytoplasm around the nucleus was not quantified because of its small volume.

The last column of table 1 shows the mean values of the area of the four cytoplasmic zones studied in the head, body and tail. The head cells were larger than those of the body. This difference was mainly due to the area of the apical zone of the cell (fig. 2 and 3a). Volume density was not actually representative of organelle size, because of the significant differences of zone areas. Relating volume densities to zone areas gave the organelle section area. The areas (in square micrometers) for the whole cells are displayed in table 2 as the results of statistical analysis. Figure 1 is the graphic representation of organelle section areas in the three studied segments of the epididymis.

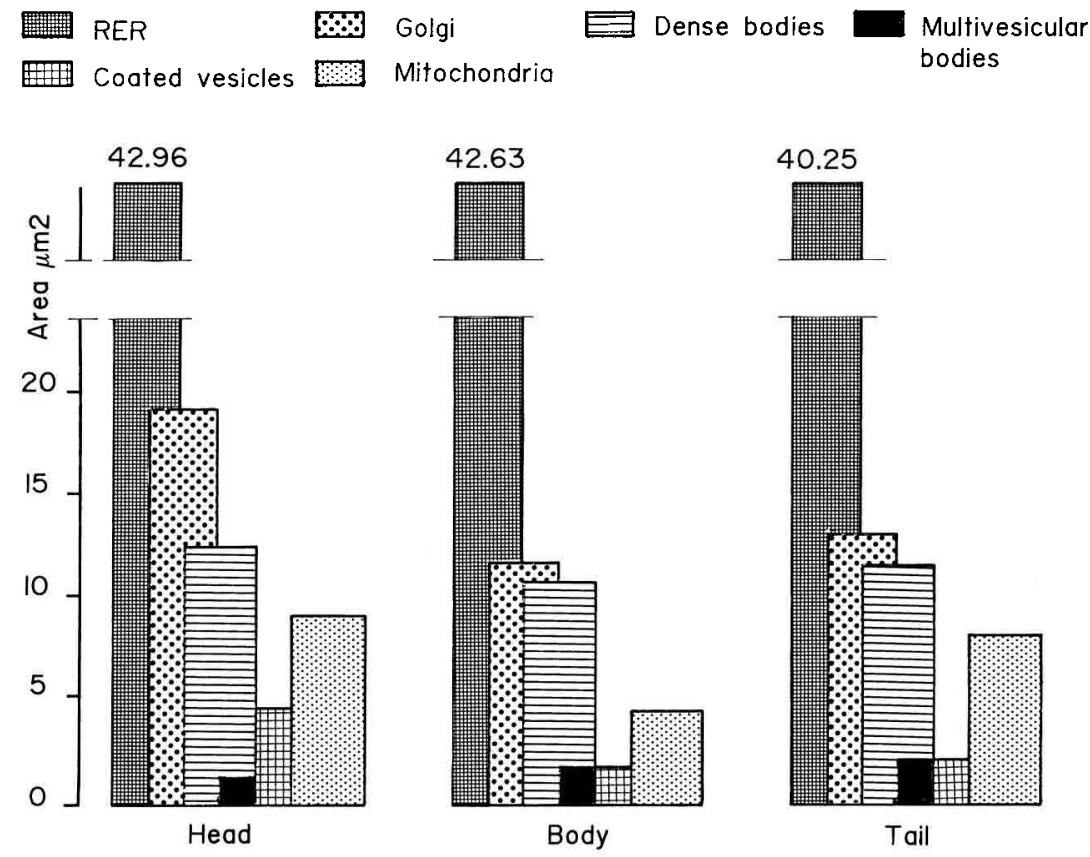

FIG. 1. - Pattern of section area of cytoplasmic organelles $\left(\mu \mathrm{m}^{2}\right)$ in the principal cells of each studied epididymal segment. 


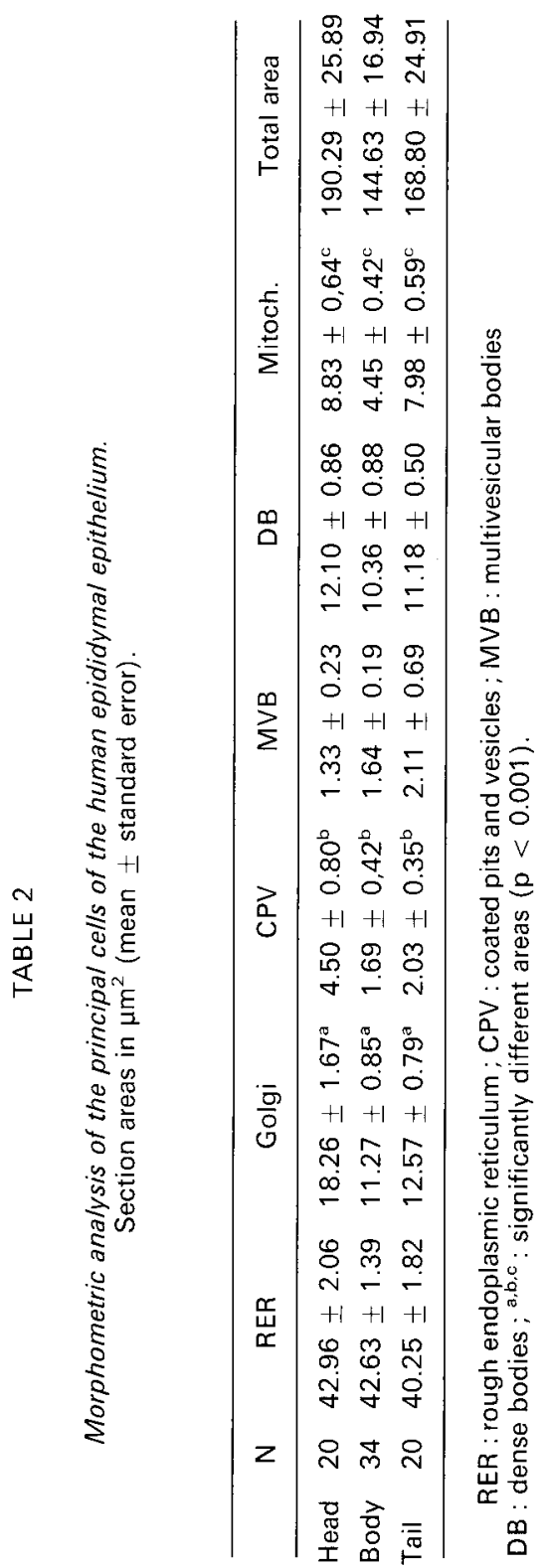




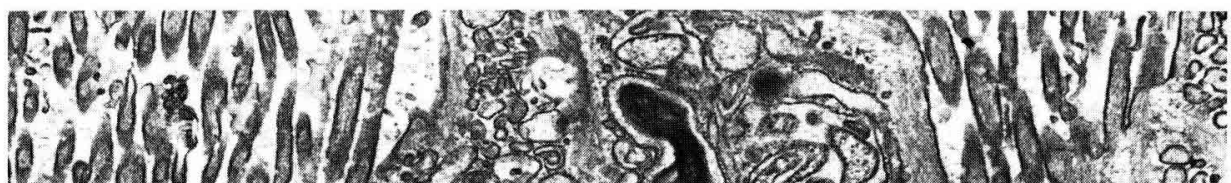

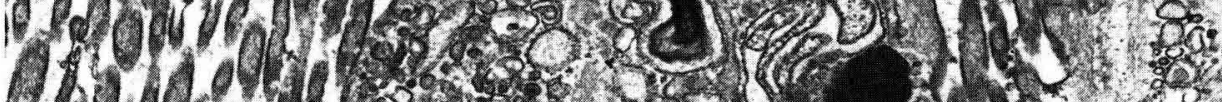

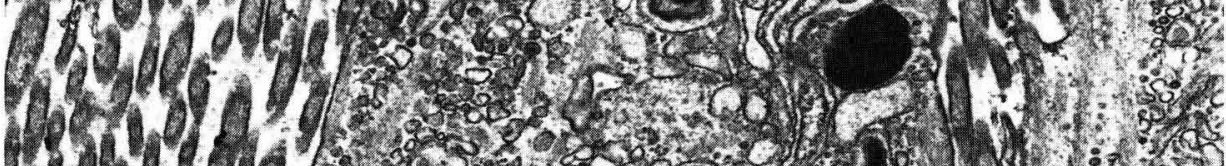

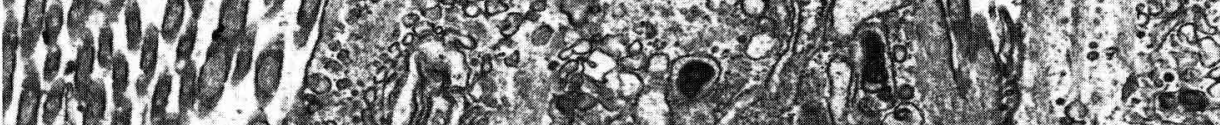

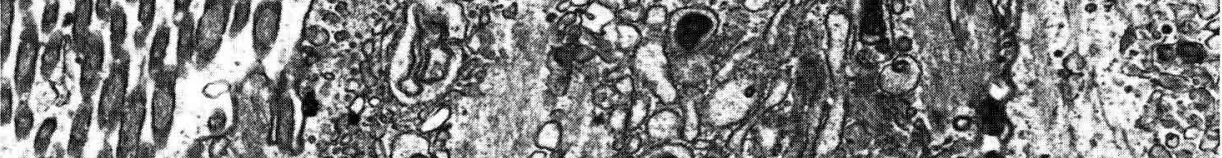

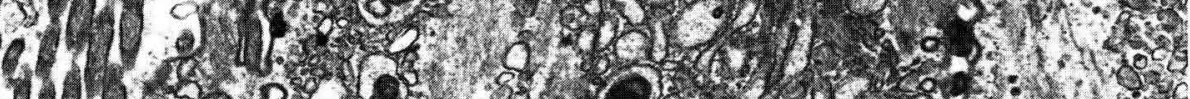

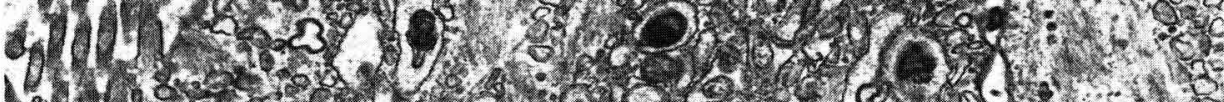

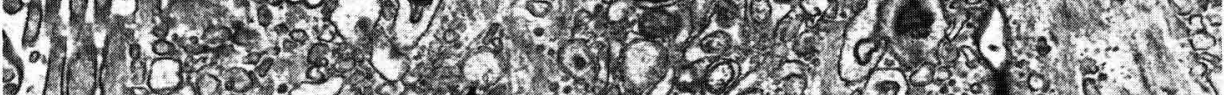

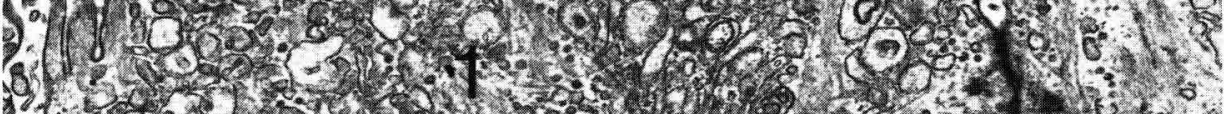

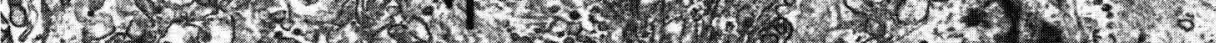

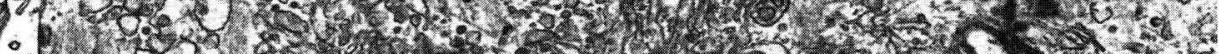

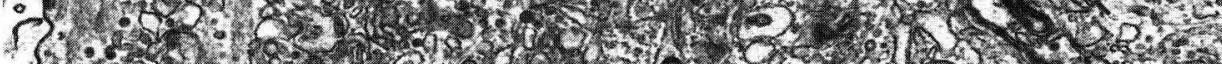

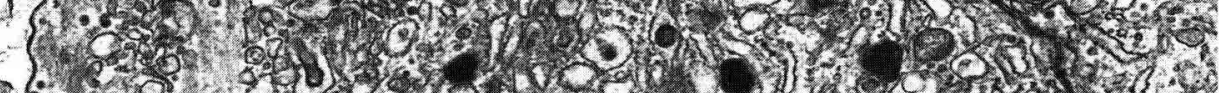

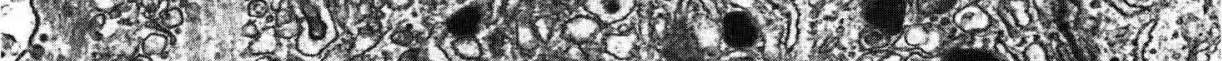
6.196.

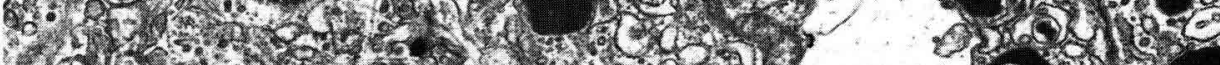

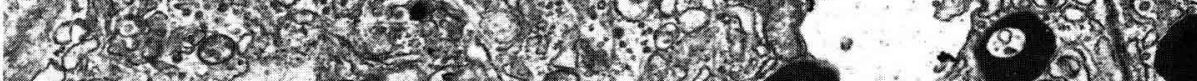

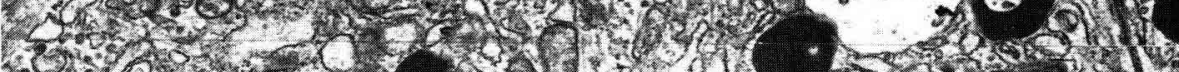
2.7\%6.

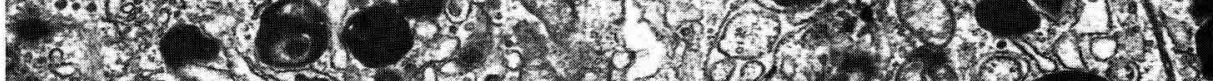

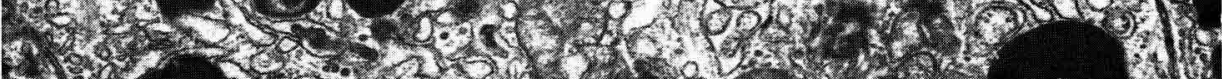
3)

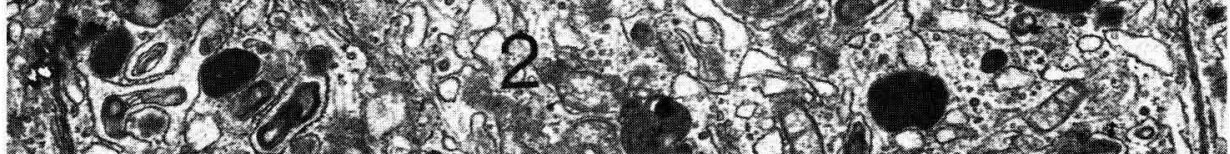

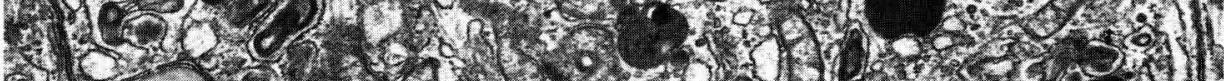

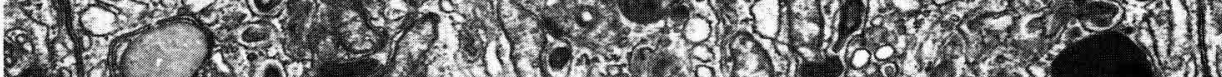

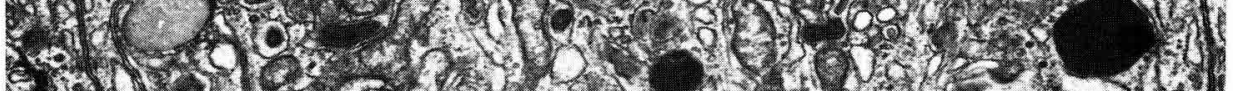
5 (3) 3 (2) ra 1 of 5 .

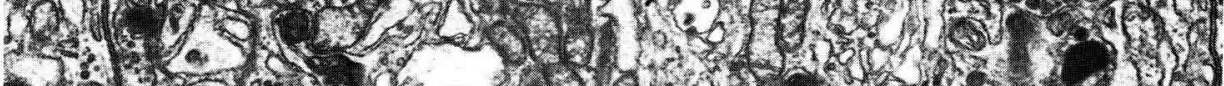

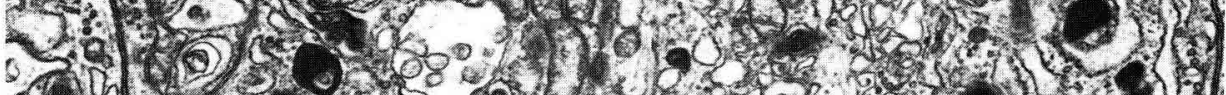

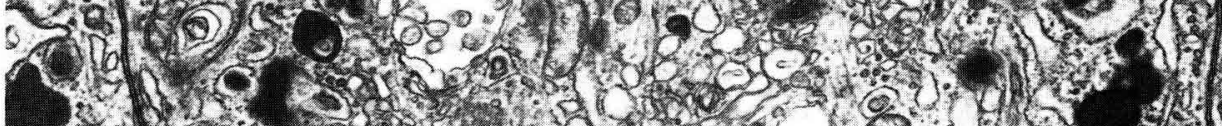

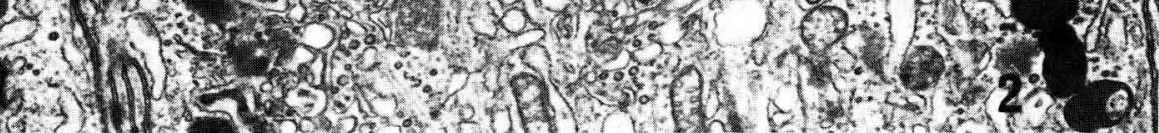


Among the cell compartments involved in absorption, coated pits and vesicles were localized almost exclusively in the supranuclear part of the cell. In the head this zone was characterized by large amounts of coated vesicles forming a network descending between bundles of microfilaments (fig. $3 b$ ). The multivesicular bodies increased from the head towards the tail of the epididymis (fig. 3c). However the low volume of these organelles was not sufficient to yield significant differences.

The dense bodies had the morphological characteristics of primary and secondary lysosomes. They were spherical and strongly osmiophilic, sometimes with lamellar whorls. Although they were present in all parts of the cells they were encountered chiefly in the middle of the supranuclear region (zone 2). Their total volume did not vary significantly along the epididymal duct.

The rough endoplasmic reticulum was evenly distributed in all the cells. In the basal area it consisted of flattened cisternae rich in ribosomes whereas in the apical zone it progressively became tubulo-vesicular in shape, the ribosomes being less numerous and sparse.

The Golgi apparatus was made up of numerous dictyosomes associated with a large amount of microvesicles. It was situated in zone 3 between the nucleus and the lysosome-rich zone. Its volume was significantly higher in the head than in the other regions.

Mitochondria were more developed in the head and tail than in the body $(p<0.01)$ and were distributed in almost the entire cell, except the apex, sometimes forming clumps in the basal zone.

\section{Discussion.}

Stereological measurements require a precise, geometrical (rather than biological) definition of the space containing the quantified structures. In their study of the structure of epithelial cells in the rat epididymis, Moore and Bedford (1979) applied stereological methods to the whole cell, without trying to determine how cytoplasmic localization would influence the amount of organelles. Conversely Paulson, Byers and Dym (1985), focusing only on coated-pits and vesicles, measured only the five apical micrometers in cells of two regions of the epididymal head.

In the present work, the large amount of dense bodies aggregated in the middle of the supranuclear zone of the cells and found along the whole epididymal duct was used as a cytological marker. On this morphological basis, it was possible to roughly separate the different cytological areas in the supranuclear cytoplasm of the principal cells of the epididymal epithelium. Although the boundaries of the areas were somewhat arbitrary, except along the plasma membrane, a comparison of equivalent compartments of cells of different sizes revealed quantitative variations in the amount of absorptive and secretory organelles according to cell subdivision and anatomical level.

FIG. 2. - Electron micrograph of the supranuclear region of a principal cell from the head of epididymis (Segment $2 \mathrm{a}$ of Holstein). Note the numerous coated-pits (CP) and coated-vesicles (CV) in the apical part of the cell (1) and the dense bodies in the deeper cytoplasmic area (2). $(\times 12000)$ 


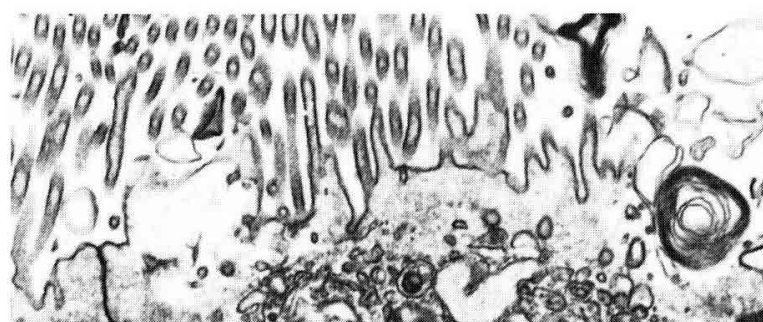
z.

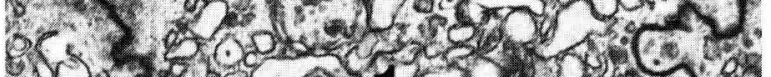

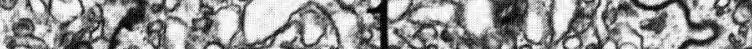

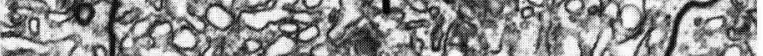

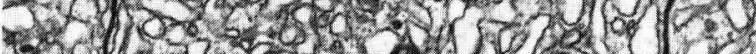

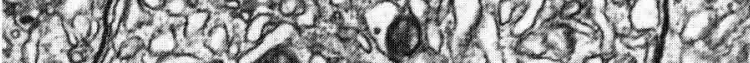

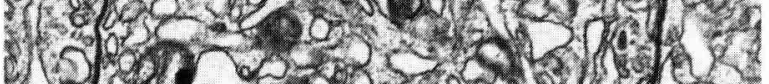

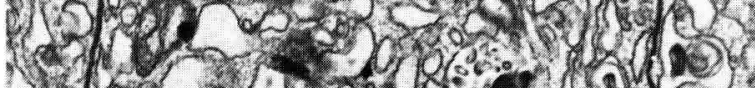
1.j.

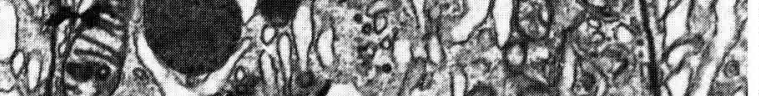
30.80 a

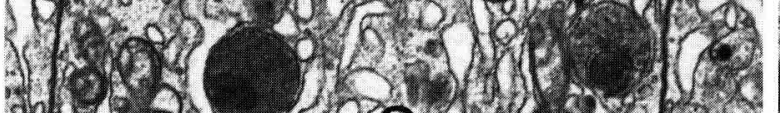

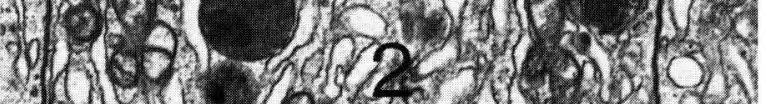
y.

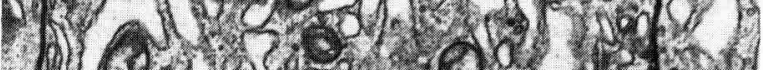

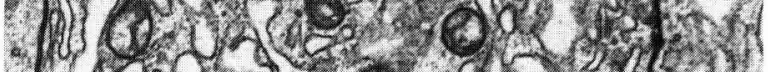
3 (1)

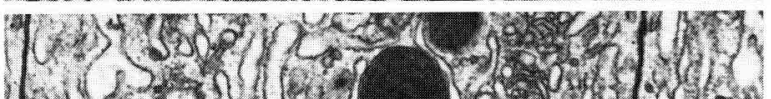

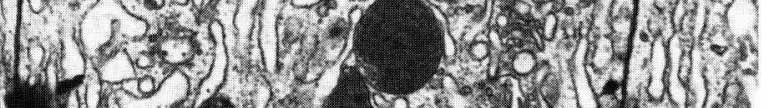
- 5 . 50 .

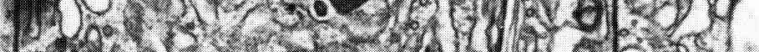

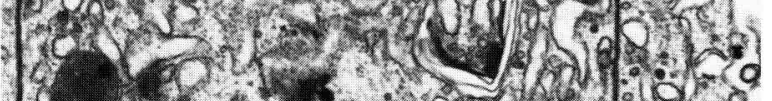

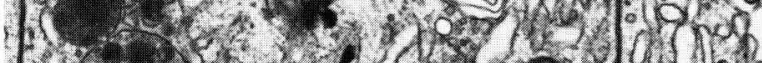

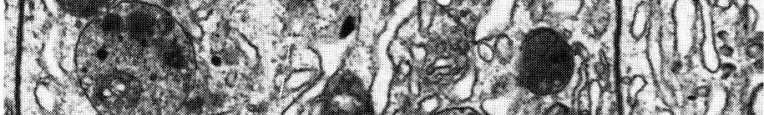

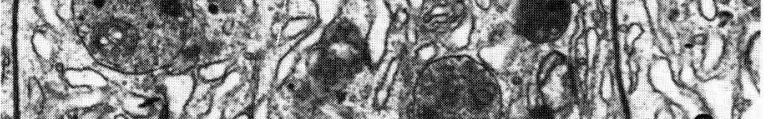
H.5. mintwy

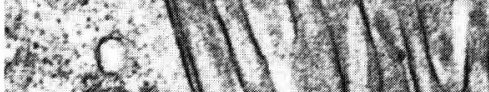

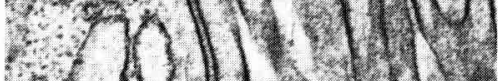
(t) $(1)=0$ (2) CPP

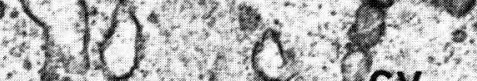

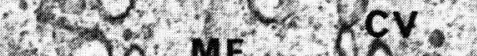
- 30 MF vich on

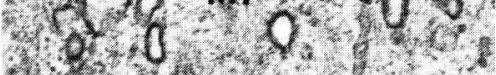
No

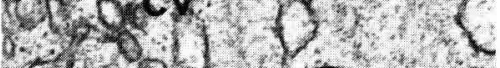

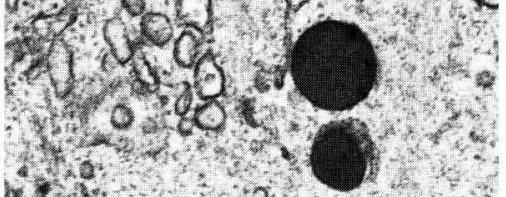
$85=2+2=$ f.

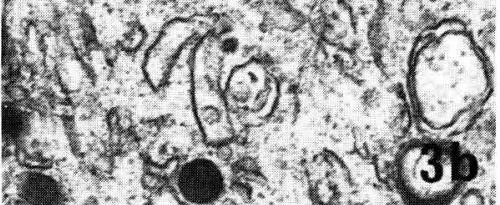

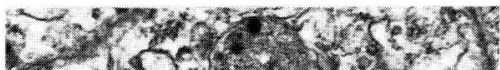

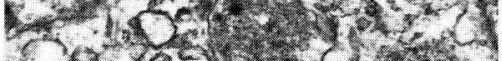

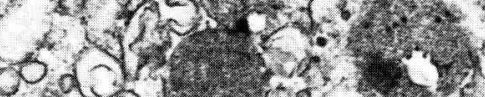

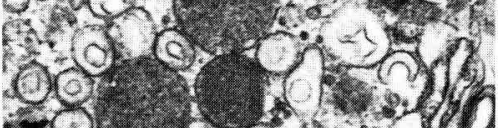
25) C.t.

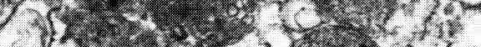

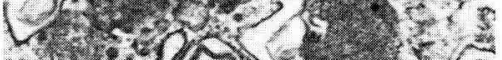

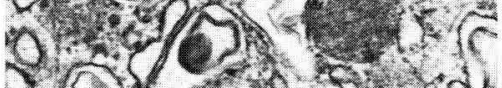

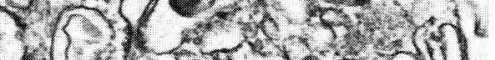

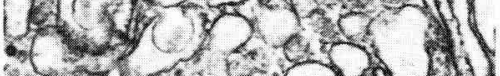

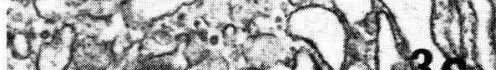
ay ens 
Endocytosis occurs in the genital male tractus via coated pits and vesicles (Friend and Farquhar, 1967 ; Hoffer, Hamilton and Fawcett, 1973), and it has been demonstrated that these structures are the site of receptor-mediated endocytosis (Goldstein, Anderson and Brown, 1979). In the epididymis, this absorption route is androgen-dependent (Pujol and Bayard, 1979). In the human epididymis the present work shows that coated-pits and vesicles were much more numerous and extensive in the head of epididymis. These findings suggest that this part of the duct is the major site of specific absorption as in rodents (Djakiew, Byers and Dym, 1984 ; Djakiew et al., 1 $₫ 35$; Paulson, Byers and Dym, 1985). These observations are in agreement with immunocytochemical evidence of endocytosis of the steroid-binding protein by the epididymal principal cells in man (Egloff et al., 1981).

During receptor-mediated endocytosis, receptor-ligand complexes reach lysosomes and are eventually degraded, recycled or simply transported (Goldstein et al., 1985). However, in man, lysosomes were evenly distributed in the whole cytoplasm of the principal cells, in spite of the decrease of receptor-mediated endocytosis in the body and tail, lysosomes being also involved in non-specific absorption (Novikoff, 1961).

Multivesicular bodies are also included in the process of endocytosis. Djakiew et al. (1985) showed that markers entering the cell in rat epididymis pass from apical vesicles to multivesicular bodies. The increasing amount of multivesicular bodies from head to tail in the human epididymis (while the volume of coated vesicles tends to diminish) suggests that endocytosis is routed otherwise by a way which is not receptor-mediated and that it occurs in the distal part of the duct. Absorption of this type has been found in the cells of the tail of epididymis in rodents (Moore and Bedford, 1979; Hinton and Hernandez, 1987). In guinea-pig, the amount of multivesicular bodies increases along the epididymal duct (Greenberg and Forssmann, 1983). The process of endocytosis, when not receptor-mediated, is usually linked to pinocytotic vesicles (Silverstein, Steinman and Cohn, 1977). However these vesicles were not found in the human epididymal cells.

The secretory activity of epididymis in man has mainly been established through biochemical analysis of seminal plasma (Cooper, 1986). Synthesis of proteins is known to be related to the extent of rough endoplasmic reticulum but no difference was found between the three anatomical regions studied in man. Therefore as the Golgi apparatus was twice as large in the head as in the other regions, it seems that glycosylated proteins were synthesized at a higher rate in the proximal part of the epididymal duct.

FIG. 3a. - Detail of the coated pits (CP) and coated-vesicles (CV) in a principal cell of the head of epididymis. The cavities are arranged as a network between large bundles of microfilaments (MF) $(\times 25000)$

FIG. 3b. - Electron micrograph of a principal cell from the body of epididymis. The apical area (1) is smaller than in the head cells. Coated-vesicles are less numerous and sparse. Dense bodies and multivesicular bodies occur in zone $2 .(x 12000)$

FIG. 3c. - Detail of multivesicular bodies in a principal cell from the tail of epididymis. $(\times 25000)$ 
The quantitative ultrastructural data on human epididymal epithelium should be correlated with histochemical and biochemical data to ascertain the involvement of each region of the epididymis in absorptive and secretory functions. However, morphometric findings are consistent with observations made in laboratory mammals although the regional cytological differences are less clear-cut in man than in rodents.

Significant variations were found in the amount of some of the main cytoplasmic organelles in the three segments belonging to the head, body and tail of the epididymis respectively. The larger amount of coated vesicles in the principal cells of the head shows that this part of the epididymis plays a major role in receptor-mediated endocytosis, while the most developed Golgi apparatus reveals an increased secretory activity related to protein synthesis.

$5^{e}$ Congrès de la Société d'Andrologie de langue française, Paris, décembre 1987.

\section{Résumé. Analyse quantitative ultrastructurale des cellules principales de l'épididyme humain.}

L'analyse morphométrique des cellules principales de l'épithélium épididymaire a été entreprise chez six hommes adultes jeunes. Des fragments ont été prélevés dans la tête, le corps et la queue de l'épididyme et étudiés en microscopie électronique. Le cytoplasme a été subdivisé sur les micrographies en quatre zones dont la surface de section a été mesurée par planimétrie et la densité de volume des principaux organites évaluée par comptage de points, ce qui a permis de calculer leur surface réelle de section. L'organisation générale des cellules principales de l'épithélium épididymaire s'est révélée identique dans les trois régions étudiées. L'analyse quantitative a montré que les cellules de la tête contiennent des volumes significativement plus élevés de vésicules revêtues et saccules de Golgi que celles du corps et de la queue. Les implications fonctionnelles de ces résultats concernant l'endocytose médiée par récepteurs et la synthèse protéique dans les différentes portions du canal épididymaire sont discutées.

\section{References}

CHALKLEY H. W., 1943. Methods for quantitative morphological analysis of tissue. J. nat. Cancer Inst., 4, 47-53.

COOPER T. G., 1986. The epididymis, sperm maturation and fertilisation. Springer Verlag, Berlin-Heidelberg.

DJAKIEW D., BYERS S. W., DYM M., 1984. Receptor-mediated endocytosis of alpha2-macroglobulin and transferrin in rat caput epididymal epithelial cells in vitro. Biol. Reprod., 31, 1073-1085.

DJAKIEW D., BYERS S. W., LEWIS D. M., DYM M., 1985. Receptor-mediated endocytosis of alpha2-macroglobulin by principal cells in the proximal caput epididymidis in vivo. $J$. Androl., 6. 190-196.

DJAKIEW D., GRISWOLD M. D., LEWIS D. M., DYM M., 1986. Micropuncture studies of receptor-mediated endocytosis of transferrin in the rat epididymis. Biol. Reprod., 34. $691-699$.

EGLOFF M., VENDRELY E., TARDIVEL-LACOMBE J., DADOUNE J. P., DEGRELLE H., $1981 . \quad$ Etude immunohistochimique du testicule et de l'épididyme humains à l'aide d'un antisérum 
monospécifique dirigé contre la protéine plasmatique liant les hormones sexuelles. $C . R$. Acad. Sci. (Paris), 295, 107-111.

FRIEND D. S., FAROUHAR M. G., 1967. Function of coated-vesicles during protein absorption in the vas deferens. $J$. Cell Biol., 35, 357-378.

GOLDSTEIN J. L., ANDERSON R. G. W., BROWN M. S., 1979. Coated-pits, coated vesicles and receptor-mediated endocytosis. Nature, 279, 679-685.

GOLDSTEIN J. L., BROWN M. S., ANDERSON R. G. W., RUSSELL D. W., SCHNEIDER W. J., 1985. Receptor-mediated endocytosis : concepts emerging from the LDL receptor system. Ann. Rev. Cell Biol., 1, 1-39.

GREENBERG J., FORSSMANN W. G., 1983. Studies of the guinea-pig epididymis. I. Ultrastructure and quantitative morphology of the principal cells. Anat. Embryol., 168, 173-194.

HINTON B. T., HERNANDEZ H., 1987. Neutral amino acid absorption by the rat epididymis. Biol. Reprod., 37, 288-292.

HOFFER A. P., HAMILTON D. W., FAWCETT D. W., 1973. The ultrastructure of the principal cells and intraepithelial leucocytes in the initial segment of the rat epididymis. Anat. Rec., 175, 169-202.

HOLSTEIN A. F., 1969. Morphologische Studien am Nebenhoden des Menschen. Zwang/. Abhandl. Geb. norm. pathol. Anat., 20, 1-91.

JONTE G., HOLSTEIN A. F., 1987. On the morphology of the transitional zones from the rete testis into ductuli efferentes and from the ductuli efferentes into the ductus epididymidis. Investigations on the human testis and epididymidis. Andrologia, 19, 398-412.

MOORE H. D. M., BEDFORD J. M., 1979. Short-term effects of androgen withdrawal on the structure of different epithelial cells in the rat epididymis. Anat. Rec., 193, 293-312.

NOVIKOFF A. B., 1961. Lysosomes and related particles, 423-488. In BRACHET J., MIRSKY A. E., The cell, vol. 2. Acad. Press, New York.

PAULSON H. L., BYERS S. W., DYM M., 1985. Morphometric analysis of coated-pits and vesicles in the proximal and distal caput epididymidis. Biol. Reprod., 32, 191-202.

PUJOL A., BAYARD F., 1979. Androgen receptors in the rat epididymis and their hormonal control. J. Reprod. Fertil., 56, 217-222.

SILVERSTEIN S. C., STEINMAN R. M., COHN Z. A., 1977. Endocytosis. Ann. Rev. Biochem., 46, $586-607$.

VENDRELY E., 1981. Histology of the epididymis in the human adult. Progr. reprod. Biol., 8, 21 -33.

WEIBEL E. R., 1969. Stereological principles for morphometry in electron microscope cytology. Int. Rev. Cytol., 26, 235-302.

WEIBEL E. R., 1979. Stereological methods. Vol. 1. Practical methods for biological morphometry. Acad. Press, London. 